\title{
Az átutazó turizmus magyarországi sajátosságai, különös tekintettel a költésre
}

\section{The features of transit tourism in Hungarian, with a special focus on spending}

\begin{abstract}
Kincses Áron Tanulmányunkban a magyarországi átutazó turizKözponti Statisztikai Hivatal E-mail: aron.kincses@ksh.hu

Tóth Géza

Központi Statisztikai Hivatal E-mail:

geza.toth@ksh.hu

Tömöri Mihály

Nyíregyházi Főiskola

E-mail:

tomori.mihaly@nye.hu

Michalkó Gábor MTA CSFK, Budapesti Corvinus Egyetem E-mail: michalko.gabor@csfk.mta.hu

Kulcsszavak: átutazó turizmus, turisztikai költés,

Magyarország

musban részt vevők turisztikai magatartását, azon belül is a költés sajátosságait mutatjuk be. Többváltozós matematikai statisztikai módszerek segítségével feltárjuk a 2009 és 2013 között Magyarországra érkező külföldiek motivációs hátterét, költésének jellemzőit, majd az átutazók kiadási struktúráját, a költésre ható tényezőket állampolgárság szerinti bontásban.

Vizsgálataink szerint a Magyarországra érkező külföldiek költési összetételében jelentős részt képviselnek az átutazók, akiknek a költése folyamatosan nő. Az átutazás legfontosabb költéstípusai az üzemanyag-vásárlás és a vendéglátóhelyi étkezés. A Magyarországon átutazó látogatók közül Románia, Szerbia (Montenegróval és Koszovóval együtt), valamint Bulgária állampolgárainak részesedése a legnagyobb. Az átutazók kiadása és számuk is kismértékben emelkedett a vizsgált időszakban, viszont az egy főre számított kiadások csökkentek. Kimutattuk, hogy ennek hátterében az országok közötti átrendeződés áll.

Az átutazásra fordított költések változását az egyes országokhoz való tartozás határozza meg leginkább. Kutatásunk alapján megállapíthatjuk, hogy az átutazás legmarkánsabb folyamatai alapvetően az általános európai trendektôl, illetve a Magyarország által az átutazók számára biztosított feltételektől függnek.
\end{abstract}


The present study focuses on the tourist behaviour of participants in Hungarian transit tourism, and on the particularities of their spending. The work with the help of multi-variable mathematicalstatistical methods explores the motivational background and spending characteristics of foreigners coming to Hungary, then it investigates the expenditure structure of transit travellers including the related influencing factors broken down by nationality for the years of 2009-2013.

According to our studies transit travellers already have a very significant share in the spending composition of foreigners arriving in Hungary, moreover their spending continues to rise. Fuel purchases and meals in restaurants are the most important types of transit spending. Among visitors travelling through Hungary, the nationals of Romania, Serbia-Montenegro and Kosovo, Bulgaria have the largest share. The spending and number of transit travellers slightly increased in recent times too, however the per capita expenditures decreased. We have shown that this is due to rearrangement between countries.

The change in transit spending is determined mostly by nationality. The most important finding of our research is that the key processes of transit

Keywords: travel basically depend on the general European transit tourism, trends and the conditions ensured by Hungary for tourist spending, transit travellers. Tourism policy should take into Hungary account this finding.

Beküldve: 2014. június 20.

Elfogadva: 2016. június 27.

\section{Bevezetés}

A turizmus a világgazdaság egyik motorja, a nemzetközi turistaforgalom átlagos évi 4\%-os növekedése, illetve a határokat átlépő utazók költésének hasonló arányú emelkedése kedvezően befolyásolja az érintett országok GDP-, foglalkoztatottság- és exportmutatóit (UNWTO 2015). A forgalom és a költés volumenének bővülésével párhuzamosan a nemzetközi turizmus értelmezési tartománya is szélesedik, amelynek

Területi Statisztika, 2016, 56(4): 455-476; DOI: 10.15196/TS560406 
eredményeként napjainkban már a 24 óránál rövidebb, országhatárokat átlépő utazásokat is e fogalomkörön belül tárgyaljuk (Cooper-Hall 2016). A szabadidős tevékenységek tér- és időbeli differenciálódása, a szolgáltatások államhatárokon átívelő igénybevehetősége, továbbá a munkavégzés helyhez kötöttségének lazulása következtében számos új utazási motiváció került fel a turizmus amúgy is tarka palettájára. Ezek tekintélyes részének kielégítésére az úgynevezett rövid vagy egynapos utazások keretében kerül sor (Wynen 2013, Yousuf-Backer 2015). A jelenséget az Európai Unió is felismerte, az Európai Parlament és a Tanács 2011-ben rendeletet ${ }^{1}$ alkotott azon utazások statisztikai számbavételének mielőbbi kidolgozására, amelyek a korábbi (1995. évi) irányelvben foglaltak szerint kimaradtak az adatgyújtésből. Magyarországon az MTA Csillagászati és Földtudományi Kutatóközpont (CSFK) Földrajztudományi Intézetében 2012 óta zajló OTKA kutatási program keretében folynak azok a vizsgálatok, amelyek az úgynevezett „láthatatlan turizmusként” értelmezhető utazások gazdasági, társadalmi és környezeti sajátosságait tárják fel (Michalkó-Rátz 2013). E program égisze alatt kezdődött (a KSH-val való együttmúködésben) Magyarország átutazó turizmusának tanulmányozása, az elsô eredmények az érintett desztinációk körvonalazását segítették elő (Kincses et al. 2014).

\section{Elméleti háttér}

Annak ellenére, hogy az átutazás Közép-Európa számos országában, köztük Ausztriában, Csehországban, Magyarországon, Szlovákiában és Szlovéniában is hosszú ideje meghatározó jelenség (az adott országba belépő külföldiek legalább egynegyede 24 órán belül a belépésitől eltérő határszakaszon kilép), a nemzetközi szakirodalom mégis meglehetôsen mostohán tekint erre a kérdésre (Bakic 1988, Johnson 1995, Hall 1998). A téma kutatásának elhanyagolását feltételezhetően magyarázó okok között magának az átutazásnak a természetét kell elsőként említeni, ugyanis egy gyors lefolyású, viszonylag zárt rendszerben zajló mobilitásról van szó, amelynek megfigyelése számos nehézségbe ütközik. Az átutazás lényege a holt idő lerövidítése, a célterület minél gyorsabb elérése, vagyis a kiindulási és a célterület közötti, gyakran önálló entitással (például állam, városállam) rendelkező szakasz legkevesebb megállással, legrövidebb tartózkodással való áthidalása. Ebből kifolyólag az idő nyomása alatt álló átutazókkal kapcsolatos adatgyüjtés roppant nehézkes, kérdőív kitöltésére, interjúzásra nem szívesen szánnak időt, a velük kapcsolatban lévő szolgáltatóktól pedig csak korlátozott információk szerezhetők be. Az átutazással összefüggő problémák kutatásában rejlő potenciál fel nem ismerésének másik lehetséges oka a jelenség szerepének,

${ }^{1}$ Az Európai Parlament és Tanács 692/2011/EU rendelete (2011. július 6.) a turizmusra vonatkozó európai statisztikákról és a 95/57/EK tanácsi irányelv hatályon kívül helyezésérôl.

Területi Statisztika, 2016, 56(4): 455-476; DOI: 10.15196/TS560406 
hatásainak lebecsülésében keresendő. Az adott országba belépő külföldiek csoportjában a turisták és a kirándulók mellett az átutazókat - az egysíkú tevékenységükből fakadó társadalmi, gazdasági, környezeti hatásokkal összefüggésben - a valós részesedésükhöz képest mind ez idáig csak elvétve figyelték meg.

Az átutazással közvetlenül foglalkozó nemzetközi szakirodalom elsősorban a repülőtereken jelentkező forgalomra koncentrál. A nemzetközi repülőtereken igénybe vehetô szerteágazó szolgáltatások, különösen a vámmentes üzletek vizsgálata (Graham 2009) mellett a különböző biztonsági szempontok, a határátlépés és a vámolás (Prager et al. 2015), a járványügyi kockázatok (Malone et al. 2009) szerepeltek a kutatásokban. Felismerték, hogy a kedvező földrajzi fekvésű, csomóponti elhelyezkedésú, jelentôs átutazó forgalmat lebonyolító repülőterek nem csupán a repülőtéri szállodákban éjszakázók sajátos kereslete, hanem a települések vonzerejére épülő dinamikus turizmusfejlesztés révén is profitálnak az átutazókból (Lohmann et al. 2009).

Az átutazást közvetetten érintő tanulmányok sorában az utazók szállításával és a környezetvédelmi kérdésekkel foglalkozókkal is találkozhatunk. A tranzitforgalom sikeres lebonyolításában közremúködő közlekedési vállalatok szerepének értékelése (Schiefelbusch et al. 2007) csakúgy a vizsgálatok tárgyát képezte, mint a magánszektor hozzájárulásának áttekintése (Gopalan-Narayan 2010). Utóbbi esetében nem csupán az informális (Michaud 1991), hanem a megosztott gazdaság (Böhler et al. 2006) szereplőinek részvételétől sem lehet az átutazás problematikájának megértése során eltekinteni. A fejlődő világ nehezen megközelíthető úti céljaiba történő eljutás, a rosszul szervezett közlekedési infrastruktúrával rendelkező területeken való „átkelés” feltételezi a helyi közösségek által biztosított szolgáltatásokat. Az átutazással összefüggésben jelentkező környezetterhelés, a fenntarthatóság elvének az érintett útvonalakon való biztosítása is fontos kérdéskör (Filimonau et al. 2014).

Az átutazók utazási szokásainak, turisztikai magatartásának feltárása elvétve jelenik meg a szakirodalomban. Az átutazás témakörén belül sajátos területet képvisel a stoppolás (Laviolette 2016), amely egyrészt életforma, másrészt a megosztott gazdaság tárgykörének perifériáján elhelyezkedő jelenség, harmadrészt a társadalmi felelősségvállalás és a szolidaritás egyik kifejeződése. Amíg a stoppolás átutazásban jelentkező hatásai valóban elhanyagolhatóak, addig a lakókocsival/lakóautóval érkezők magatartása már a hagyományos értelemben vett turizmusban is vizsgálható. A lakókocsi/lakóautó biztosította szabadságnak és rugalmas döntéshozatalnak köszönhetően számos esetben előfordul, hogy az átutazási motiváció az adott desztinációban való éjszakázással párosul (Green 1978). Ez lehet tervezett (kiszámított) és kialakulhat spontán (megtetszik az utasoknak a hely, ahol éppen megpihentek) vagy kényszer, illetve a körülmények hatására (váratlan esemény, közlekedési dugó stb.) is. A lakókocsi/lakóautó használata (útdíj, parkolási díj, üzemanyag), továbbá a benne utazók ellátása (kiskereskedelem, vendéglátás), esetleg szabadidős tevékenysége vagy éjszakázása, a jármú szervizelése már érdemi költést generálhat.

Területi Statisztika, 2016, 56(4): 455-476; DOI: 10.15196/TS560406 
Az átutazás - mivel az esetek többségében nem párosul az adott országban való éjszakázással - a szálláshely-statisztikai adatgyúités körén kívül eső jelenség (Parocco et al. 2012). Az Európai Unió schengeni övezetéhez tartozó országok többségében nem regisztrálják az uniós állampolgárok áramlását, így becsült, származtatott vagy statisztikai mintavételi eljárásból származó adatok alapján értékelik a jelenséget (VoloGiambalvo 2008). A nemzetközi szakirodalom unobserved vagy unmeasured turizmusként említi a személyforgalomban jelentkező átutazáshoz kötődő mobilitást (De Cantis et al. 2015), a magyar nyelvú szakirodalom a láthatatlan turizmus kifejezést használja a 24 óránál rövidebb, illetve regisztrált szálláshelyhez nem kötődő utazásokra (Michalkó-Rátz 2013).

A költés a turisztikai magatartás legelemibb része (Rátz 2004). A költés teszi az utazót turistává, a szolgáltatások ellenérték fejében történő igénybevételének köszönhetően válik a környezetváltozásban érintett személy az adott ország(ok) turizmusát generáló aktorrá. A költés az utazást meghatározó számos tényezővel korrelál, alapvetően a motivációval áll a legszorosabb összefüggésben (Suh-McAvoy 2005). Egy átlagos turista költésstruktúrájának összetevői között a szállásra, a vendéglátásra, a programokra és az áruvásárlásra fordított kiadások megközelítően azonos arányban vannak jelen (Michalkó 2012).

\section{Módszer}

A Központi Statisztikai Hivatal a Magyarországon átutazókról 2007 óta készít felmérést „A külföldiek magyarországi turisztikai és egyéb kiadásai (negyedéves)” kérdőív részeként. A felmérés megfigyelési köre a határon nem tehergépkocsival kilépő külföldi és belépő magyar állampolgárokra terjed ki. A megfigyelés mintája rétegzett, nem valószínűségi minta. Az éves mintanagyság 2008-tól körülbelül 60 ezer kérdőív a teljes kérdőív vonatkozásában, amelyen belül az átutazókkal kapcsolatos minta elemszáma 14-15 ezer között ingadozik. A napok kiválasztása szisztematikus, véletlen. Az adatfelvétel személyes kikérdezés útján történik.

Kutatásunkban elsősorban öt év adatait vizsgáltuk. A 2009 és 2013 közötti időszak kiválasztásának alapvető oka az, hogy a gazdasági válság utáni időszak adatai nyilvánvalóan jelentősen különböznek az azt megelőző időszakétól. 2009 után viszont kimutatható, hogy a válság utáni kilábalás milyen formában jelenik meg az átutazás adataiban.

\section{A külföldiek turisztikai tulajdonságai}

A külföldi turisták magyarországi költéseit költségnemenként, motivációs cél és állampolgárság szerint is csoportosíthatjuk. A turisták magyarországi költései lassú ütemben, de folyamatosan növekszenek. A vizsgált öt év alatt a turisták által elköltött

Területi Statisztika, 2016, 56(4): 455-476; DOI: 10.15196/TS560406 
pénzek 6\%-kal emelkedtek. A legnagyobb súlyai az ajándékok vásárlásának és a szállás étkezéssel költésnemeknek vannak. A legdinamikusabban a nemzetközi közlekedésre (205\%), kulturális programokra (192\%), szórakozásra (177\%) és a gyógyászatra (173\%) való kifizetések növekedtek 2009-ről 2013-ra.

\section{A külföldi turisták összes költései költségnemenként}

Total spending of foreign tourists by types of spending, 1000 HUF

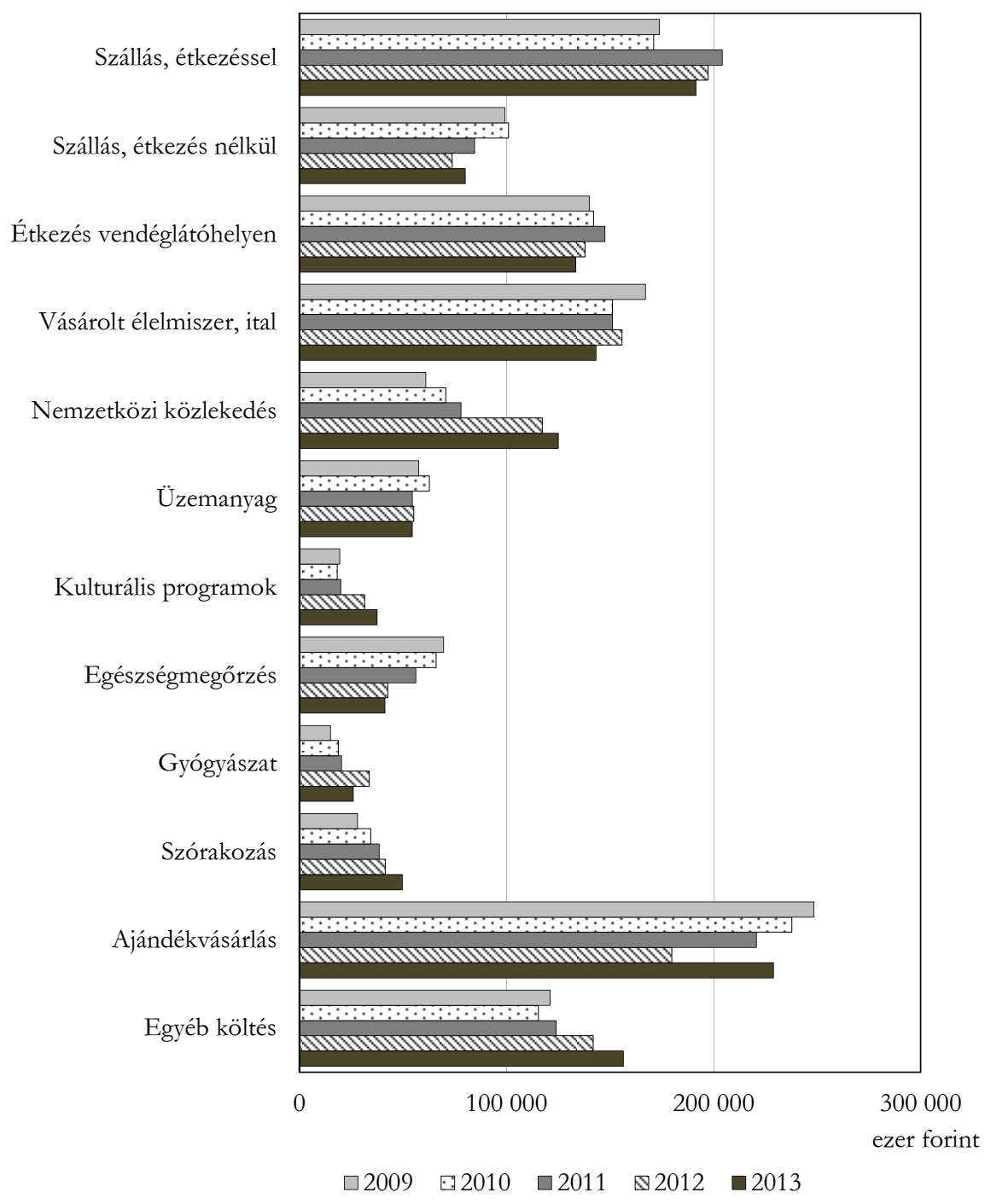

A költésnemek mellett motiváció szerint is bonthatjuk a turisták költéseit.

Területi Statisztika, 2016, 56(4): 455-476; DOI: 10.15196/TS560406 
A külföldi turisták összes költésének megoszlása motivációk szerint

Distribution of total spending of foreign tourists by motivation

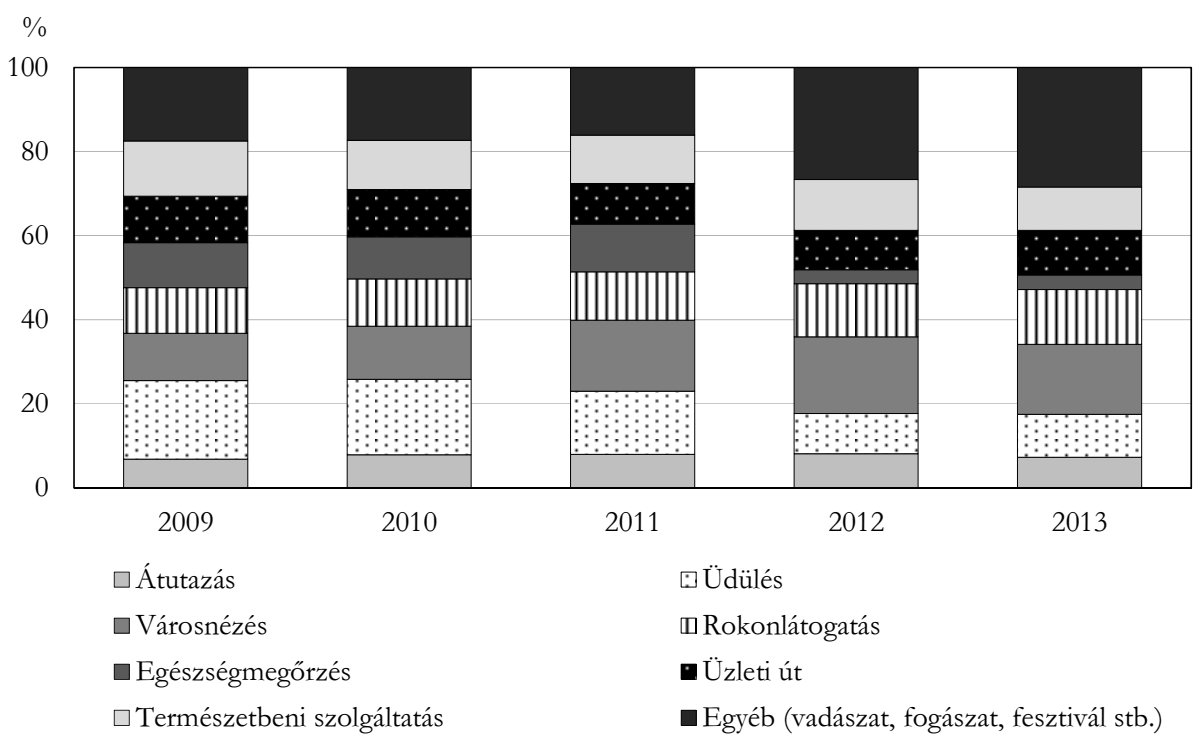

A városnézés és a rokonlátogatás a külföldi turisták legjelentősebb motivációi Magyarországon. A vizsgált öt év alatt a motivációk részesedése a külföldi turisták forintban kifejezett költéseiből jelentősen megváltozott. A „klasszikus” célok (mint az egészségmegőrzés, üdülés) visszaszorulóban vannak, míg a vadászat, a fogászat, a városnézés aránya és összege folyamatosan, dinamikusan növekszik.

\section{A turizmus motivációinak súlya az összes költésekből és ezek változásai}

Changes in the weight of tourism motivations within all spending (\%)

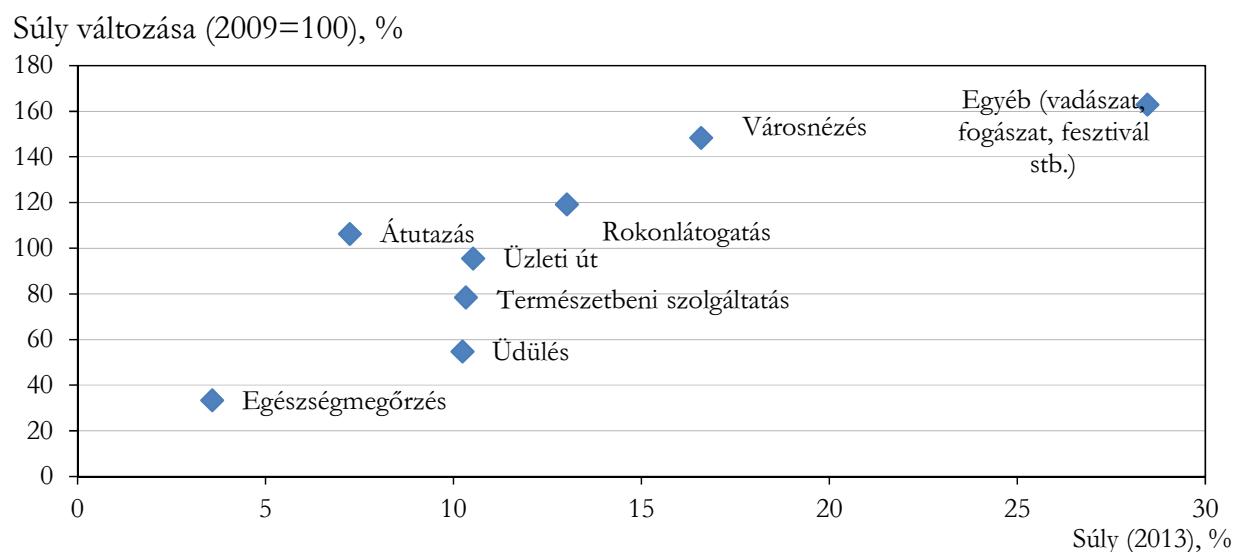

Területi Statisztika, 2016, 56(4): 455-476; DOI: 10.15196/TS560406 
A motivációk és a költségnemek nem függetlenek egymástól. A minőségi ismérvek közötti kapcsolat szorosságát az ún. szorossági mérőszámok segítségével vizsgáljuk. Az asszociációs elemzés alapgondolata a függetlenség feltételezésével számított gyakoriság. A kontingenciatáblázat keresztösszefüggéseket magában foglaló, teljes eseményrendszert tartalmazó valószínűségi táblázat.

\section{Keresztösszefüggések}

1. táblázat

Cross-relationship

\begin{tabular}{|c|c|c|c|}
\hline & $\mathrm{x}_{1}$ & $\mathrm{x}_{2}$ & $\sum$ \\
\hline $\mathrm{y}_{1}$ & $\mathrm{p}_{11}$ & $\mathrm{p}_{12}$ & $\mathrm{p}_{1 .}$ \\
\hline $\mathrm{y}_{2}$ & $\mathrm{p}_{21}$ & $\mathrm{p}_{22}$ & $\mathrm{p}_{2 .}$ \\
\hline$\sum$ & $\mathrm{p} .1$ & $\mathrm{p}_{2}$ & 1 \\
\hline
\end{tabular}

Például 2x2-es táblázat (nem szimmetrikus), ahol pij=P(X=xi, Y=yj), i,j=1,2. Ekkor a két változó függetlenségét a

méri.

$$
\Phi^{2}=\sum_{i=1}^{I} \sum_{j=1}^{J} \frac{\left(p_{i j}-p_{i .} \cdot p_{j .}\right)^{2}}{p_{i .} \cdot p_{j .}}
$$

- $\Phi^{2}$ mennyiség normálásával adódik a Pearson-féle statisztika:

$$
P=\sqrt{\frac{\Phi^{2}}{\Phi^{2}+1}}
$$

- $\mathrm{P}=0$ függetlenség

- $\mathrm{P}=1 \quad$ függvényszerü

- $0 \leq \mathrm{P} \leq 1$ sztochasztikus kapcsolat

2. táblázat

A külföldiek költségnemek és motivációk közötti asszociációs kapcsolatainak szorossága

Closeness of associative relations between cost types and motivations in case of foreigners

\begin{tabular}{c|c|c|c}
\hline Év & $\Phi^{2}$ & $\mathrm{P}$ & $\begin{array}{c}\text { Az átutazás részesedése } \\
\Phi^{2} \text {-ből, \% }\end{array}$ \\
\hline 2009 & 0,755 & 0,656 & 17,177 \\
2010 & 0,734 & 0,651 & 17,065 \\
2011 & 0,696 & 0,641 & 19,690 \\
2012 & 0,611 & 0,616 & 21,363 \\
2013 & 0,571 & 0,603 & 24,335
\end{tabular}


Közepesen erős, bár folyamatosan csökkenő kapcsolat van a külföldiek motivációi és a költésnemek között. Miközben öt év alatt együttesen 5 százalékponttal csökkent a Pearson-féle asszociációs együttható értéke, addig a költségnemek és az átutazás függősége tovább emelkedett. Azaz az átutazásnak vannak tipikus költségtípusai, míg a többi célra ez kevésbé érvényes.

Az átutazás a teljes külföldi turisztikai költésekből az üzemanyag-vásárlás 49, a vendéglátóhelyen történő étkezések 14\%-át teszi ki, miközben egészségmegőrzésre, kulturális programokra, gyógyászatra stb. nem költenek az átutazók.

\section{Az átutazás szerepe a magyarországi nemzetközi turizmusban}

2013-ban mintegy 15563 ezer fô érkezett Magyarországra átutazási céllal, és látogatásuk során 91914 millió forintot költöttek el. 2009 óta a látogatószám $6 \%$-kal, a kiadás folyó áron számolva mintegy 12\%-kal nőtt. Ha a látogatók számának alakulásával vetjük össze az átutazókat, akkor megállapíthatjuk, hogy a bázisévhez és az összes látogatóhoz képest számuk mintegy 1 százalékponttal kisebb, míg költésük 6 százalékponttal nagyobb mértékben nőtt.

\section{A Magyarországra átutazási céllal érkező külföldi látogatók száma és költése a 2009. évi százalékában}

Number and spending of foreign transit visitors to Hungary as a percentage of 2009

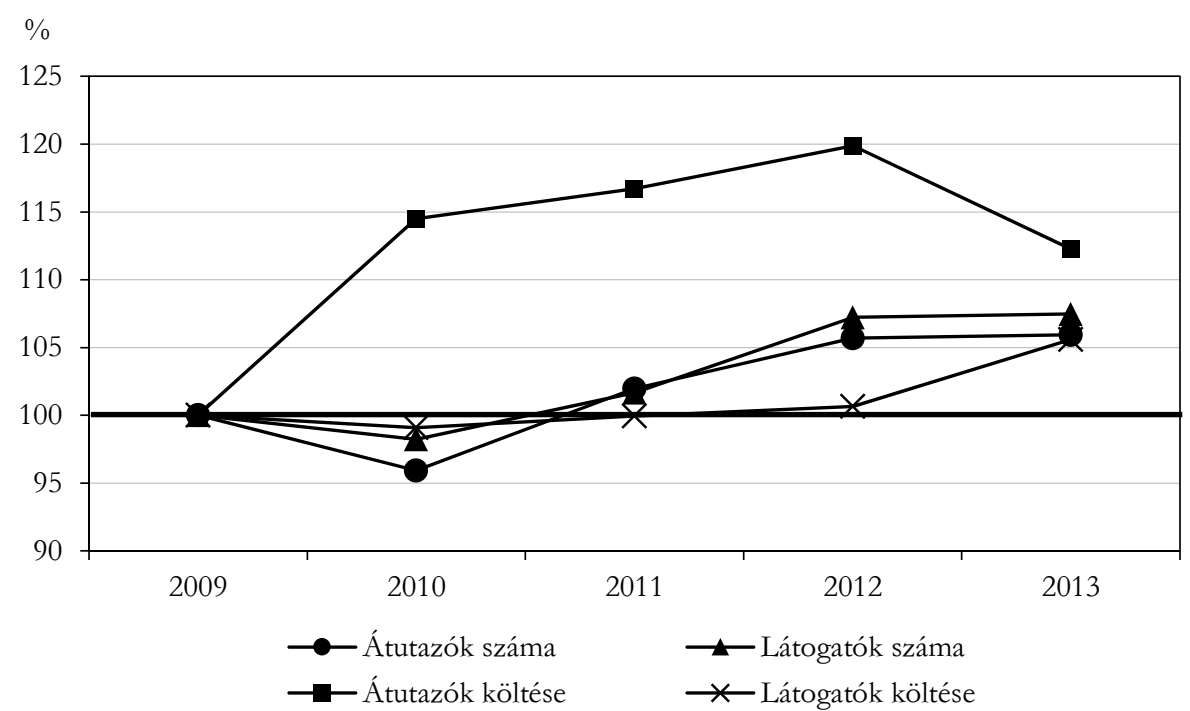

Mint azt a 3-4. táblázatok mutatják, 2009 és 2013 között az átutazók részesedése a Magyarországra érkező külföldieknek több mint egyharmadát tette ki. Részesedésük a tartózkodási időből 15-16\%-os, a költésekből 7-8\%-os volt, és az egyes évek között

Területi Statisztika, 2016, 56(4): 455-476; DOI: 10.15196/TS560406 
csak minimálisan ingadozott. Az egy főre jutó kiadás az átutazók esetében a külföldi látogatók kiadásainak 18-20\%-át tette ki. Az átlagos tartózkodási idő a tevékenység jellegéből adódóan „csak” 1 nap, bár kismértékben emelkedett.

3. táblázat

Az átutazók részesedése a Magyarországra érkező külföldi látogatók számából, tartózkodási idejéből és kiadásaiból

Share of transit visitors in the number, place of residence and expenditures of foreign visitors to Hungary

\begin{tabular}{c|c|c|c}
\hline Év & Szám & Tartózkodási idő & Kiadás \\
\hline 2009 & 36,2 & 15,6 & 6,8 \\
2010 & 35,3 & 15,4 & 7,9 \\
2011 & 36,3 & 16,0 & 8,0 \\
2012 & 35,6 & 16,6 & 8,1 \\
2013 & 35,6 & 16,2 & 7,2
\end{tabular}

Az átutazók és a külföldi látogatók kiadásának és

4. táblázat tartózkodási idejének összevetése

Comparing the spending and length of stay of transit travellers and visitors

\begin{tabular}{c|c|c|c|c}
\hline \multirow{2}{*}{ Év } & \multicolumn{2}{|c|}{ Egy före jutó kiadás, ezer forint } & \multicolumn{2}{c}{ Átlagos tartózkodási idő, nap } \\
\cline { 2 - 5 } & átutazás & összesen & átutazás & összesen \\
\hline 2009 & 5,6 & 29,6 & 1,03 & 2,39 \\
2010 & 6,7 & 29,8 & 1,05 & 2,4 \\
2011 & 6,4 & 29,1 & 1,06 & 2,4 \\
2012 & 6,3 & 27,7 & 1,07 & 2,29 \\
2013 & 5,9 & 29 & 1,06 & 2,33
\end{tabular}

\section{Átutazási célú turizmus állampolgárság szerint}

Az átutazók országok szerinti jellemzését a 2013. évi adatok tükrében végeztük el. Elemzésünkben csak azokat az országokat szerepeltettük, amelyek esetében a minta elemszáma 100 fölötti, s így a velük kapcsolatos eredmények statisztikailag relevánsak.

Az átutazó turizmus jellegéből fakadóan korlátozott földrajzi távolságon belül képes hatást kifejteni. Így főként az európai, azon belül is a Magyarországhoz közelebbi országok turistáinak költéseit mutathatjuk ki hazánkban.

A Magyarországon átutazó látogatók között Románia, Szerbia (Montenegróval és Koszovóval együtt), valamint Bulgária állampolgárai emelkednek ki. A látogatók 
száma, tartózkodási ideje és kiadásai szerint is e három ország teszi ki a Magyarországon átutazók több mint felét. Az átlagos tartózkodási idő Olaszország, Németország és Bulgária állampolgárai esetében a legmagasabb. Körükben egyre gyakoribb, hogy az átutazást - nyilván a hosszú út következtében - megszakítják, és valamely szálláshelyen megszállva, útjukat másnap folytatják céljuk felé.

Az egy látogatóra jutó költés Ukrajna állampolgárai esetében a legnagyobb, akiket az olaszok és a németek követnek.

\section{A Magyarországon átutazók részesedése és főbb jellemzői kibocsátó országok szerint, 2013}

Share and main features of those travelling through Hungary

by source country, 2013

\begin{tabular}{|c|c|c|c|c|c|}
\hline \multirow[b]{2}{*}{ Ország } & \multicolumn{3}{|c|}{ Részesedés, \% } & \multirow{2}{*}{$\begin{array}{l}\text { Átlagos } \\
\text { tartózkodási } \\
\text { idő, nap }\end{array}$} & \multirow{2}{*}{$\begin{array}{l}\text { Egy látogatóra } \\
\text { jutó kiadás, } \\
\text { ezer forint }\end{array}$} \\
\hline & szám & $\begin{array}{c}\text { tartózkodási } \\
\text { idő }\end{array}$ & kiadás & & \\
\hline Összesen & 100,0 & 100,0 & 100,0 & 1,06 & 5,91 \\
\hline Ebből: & & & & & \\
\hline Ausztria & 4,7 & 4,6 & 3,7 & 1,02 & 4,67 \\
\hline Bulgária & 7,2 & 7,4 & 8,8 & 1,09 & 7,25 \\
\hline Csehország & 3,3 & 3,4 & 3,2 & 1,07 & 5,57 \\
\hline Hollandia & 0,6 & 0,6 & 0,7 & 1,08 & 7,04 \\
\hline Horvátország & 2,6 & 2,4 & 1,5 & 1,00 & 3,33 \\
\hline Lengyelország & 7,3 & 7,2 & 6,4 & 1,04 & 5,24 \\
\hline Németország & 5,5 & 5,8 & 7,3 & 1,12 & 7,85 \\
\hline Olaszország & 1,5 & 1,6 & 2,3 & 1,13 & 9,23 \\
\hline Románia & 32,5 & 33,0 & 32,6 & 1,07 & 5,92 \\
\hline Szerbiaa) & 13,6 & 13,3 & 11,5 & 1,03 & 4,99 \\
\hline Szlovákia & 5,2 & 4,9 & 3,3 & 1,01 & 3,78 \\
\hline Szlovénia & 1,1 & 1,1 & 0,5 & 1,00 & 2,44 \\
\hline Ukrajna & 5,1 & 5,2 & 8,3 & 1,08 & 9,61 \\
\hline
\end{tabular}

a) Montenegróval és Koszovóval együtt.

Az átutazók magyarországi költésének legfontosabb része természetesen az üzemanyag-vásárlás, ami a kiadásaik közel 30\%-át teszi ki. Ezután a költés mintegy ötödével következik a vendéglátóhelyen történő étkezés, s ettől kissé lemaradva a vásárolt ital, illetve élelmiszer. További fontos kiadási tételek az egyéb költés, valamint az ajándékvásárlás.

Területi Statisztika, 2016, 56(4): 455-476; DOI: 10.15196/TS560406 


\section{Az átutazókra jellemző legfontosabb költéstípusok részesedése az összes költésükből, 2013}

Share of main types of spending characteristic of transit visitors in their total spending

\begin{tabular}{|c|c|c|c|c|c|c|}
\hline Ország & $\begin{array}{l}\text { Szállás, } \\
\text { étkezéssel }\end{array}$ & $\begin{array}{c}\text { Étkezés } \\
\text { vendéglátó- } \\
\text { helyen }\end{array}$ & $\begin{array}{c}\text { Vásárolt } \\
\text { élelmiszer, } \\
\text { ital }\end{array}$ & Üzemanyag & Ajándék & $\begin{array}{l}\text { Egyéb } \\
\text { költés }\end{array}$ \\
\hline Ausztria & 2,7 & 20,1 & 12,6 & 30,8 & 21,9 & 10,1 \\
\hline Bulgária & 3,4 & 18,5 & 12,7 & 39,6 & 8,5 & 14,7 \\
\hline Csehország & 6,0 & 21,9 & 11,7 & 36,9 & 5,1 & 15,6 \\
\hline Hollandia & 5,3 & 20,8 & 14,2 & 33,7 & 20,2 & 5,5 \\
\hline Horvátország & 0,0 & 20,8 & 19,6 & 23,2 & 6,0 & 28,2 \\
\hline Szerbia ${ }^{a)}$ & 1,8 & 20,4 & 19,9 & 26,1 & 15,8 & 11,8 \\
\hline Lengyelország & 3,6 & 21,9 & 12,3 & 38,9 & 6,0 & 14,0 \\
\hline Németország & 6,1 & 22,7 & 12,0 & 31,7 & 14,1 & 10,9 \\
\hline Olaszország & 6,1 & 23,0 & 11,3 & 31,2 & 16,6 & 11,5 \\
\hline Románia & 3,3 & 18,5 & 20,5 & 23,7 & 13,5 & 19,2 \\
\hline Szlovákia & 1,1 & 18,0 & 11,3 & 40,4 & 6,0 & 21,6 \\
\hline Szlovénia & 0,0 & 25,5 & 14,3 & 26,2 & 7,9 & 23,0 \\
\hline Ukrajna & 2,0 & 24,4 & 22,5 & 21,9 & 12,0 & 12,7 \\
\hline Átlag & 3,2 & 20,2 & 17,3 & 28,8 & 12,4 & 15,6 \\
\hline
\end{tabular}

a) Montenegróval és Koszovóval együtt.

2013-ra az átutazó turisták kiadása és száma is kismértékben emelkedett 2009-hez képest. Az egy látogatóra jutó kiadás 5,91 ezer forintról 5,57 ezer forintra csökkent.

A fóátlag-, a részátlag- és az összetételhatás-indexek segítségével elemezzük tovább az átutazó turizmus magyarországi szerkezetét.

Az alábbi jelöléseket használjuk:

$$
\begin{aligned}
& I^{\prime}=\frac{\sum B_{j 1} V_{j 1}}{\sum B_{j 1}}: \frac{\sum B_{j 1} V_{j 0}}{\sum B_{j 1}}=\frac{\sum B_{j 1} V_{j 1}}{\sum B_{j 1} V_{j 0}} \\
& I^{\prime \prime}=\frac{\sum B_{j 1} V_{j 0}}{\sum B_{j 1}}: \frac{\sum B_{j 0} V_{j 0}}{\sum B_{j 0}} \\
& I=\bar{V}_{1}: \bar{V}_{0}=\frac{\sum A_{j 1}}{\sum B_{j 1}}: \frac{\sum A_{j 0}}{\sum B_{j 0}}==\frac{\sum A_{j 1}}{\sum A_{j 0}}: \frac{\sum B_{j 1}}{\sum B_{j 0}}=\frac{\sum B_{j 1} V_{j 1}}{\sum B_{j 1}}: \frac{\sum B_{j 0} V_{j 0}}{\sum B_{j 0}}
\end{aligned}
$$


Átutazó turizmus a látogatók száma és kiadásai szerint, kibocsátó országonként

Transit tourism by number and spending and nationality of tourists

\begin{tabular}{|c|c|c|c|c|c|c|}
\hline \multirow[b]{2}{*}{ Ország } & \multicolumn{3}{|c|}{2009} & \multicolumn{3}{|c|}{2013} \\
\hline & $\begin{array}{c}\text { szám, fö } \\
\left(\mathrm{B}_{0}\right)\end{array}$ & $\begin{array}{l}\text { kiadás, } \\
\text { ezer forint } \\
\quad\left(\mathrm{A}_{0}\right)\end{array}$ & $\begin{array}{l}\text { egy látoga- } \\
\text { tóra jutó } \\
\text { kiadás, } \\
\text { ezer forint } \\
\left(\mathrm{V}_{0}\right)\end{array}$ & $\begin{array}{l}\text { szám, fö } \\
\left(\mathrm{B}_{1}\right)\end{array}$ & $\begin{array}{l}\text { kiadás, } \\
\text { ezer forint } \\
\quad\left(A_{1}\right)\end{array}$ & $\begin{array}{l}\text { egy látoga- } \\
\text { tóra jutó } \\
\text { kiadás, } \\
\text { ezer forint } \\
\left(V_{1}\right)\end{array}$ \\
\hline Ausztria & 610150 & 4722363 & 7,74 & 737167 & 3442160 & 4,67 \\
\hline Bulgária & - & - & - & 1118328 & 8107816 & 7,25 \\
\hline Csehország & 656343 & 2397038 & 3,65 & 521254 & 2904563 & 5,57 \\
\hline Hollandia & 115411 & 773133 & 6,70 & 90672 & 638031 & 7,04 \\
\hline Horvátország & 328784 & 2247046 & 6,83 & 400621 & 1335655 & 3,33 \\
\hline Lengyelország & 914063 & 4580746 & 5,01 & 1130210 & 5926767 & 5,24 \\
\hline Németország & 970348 & 6623624 & 6,83 & 853517 & 6698591 & 7,85 \\
\hline Olaszország & 252584 & 1590964 & 6,30 & 233682 & 2155759 & 9,23 \\
\hline Románia & 5424806 & 25303358 & 4,66 & 5065355 & 29988409 & 5,92 \\
\hline Szerbiaa) & 1140318 & 8620381 & 7,56 & 2122500 & 10591261 & 4,99 \\
\hline Szlovákia & 1050741 & 2988138 & 2,84 & 802685 & 3034746 & 3,78 \\
\hline Szlovénia & 146487 & 381116 & 2,60 & 176038 & 429404 & 2,44 \\
\hline Ukrajna & 618018 & 5435836 & 8,80 & 791861 & 7609932 & 9,61 \\
\hline Egyéb & 2463683 & 16207534 & 6,58 & 1519312 & 9050732 & 5,96 \\
\hline Összesen & 14691736 & 81871277 & 5,57 & 15563202 & 91913827 & 5,91 \\
\hline
\end{tabular}

a) Montenegróval együtt.

Az elemzés alapján megállapítható, hogy a részviszonyszámok változása okozza a pozitív hatást a kiadásokban, míg az összetétel változása, pontosabban a részsokaság összetételében bekövetkezett változás (országok közötti átrendeződés) negatív hatást gyakorol a fóátlagindexre.

$$
\begin{aligned}
& I=105,98 \\
& I^{\prime}=110,36 \\
& I^{\prime \prime}=96,04
\end{aligned}
$$

A költési szerkezet 2010-ről 2013-ra történt változását shift-share analízis segítségével vizsgáltuk tovább. A módszer szakirodalmi háttere meglehetősen bőséges, melyen belül a turisztikai alkalmazásokra is számos példa akadt (Houston 1967, StevensMoore 1980, Selting-Loveridge 1992, Andrikopolous-Carvalho 1990, Fuchs et al.

Területi Statisztika, 2016, 56(4): 455-476; DOI: 10.15196/TS560406 
2000, Sirakaya et al. 2002, Toh et al. 2004, Yasin et al. 2004). Kutatásunkban e munkákra alapoztunk, s így a módszer részletes ismertetésétől, illetve különböző megközelítési lehetőségeitől itt eltekintünk.

A következőkben shift-share analízisünkben azt vizsgáltuk, hogy a költések 2010-ról 2013-ra történt változását mennyiben magyarázza az összes ország átutazóira jellemző költésszerkezęt, illetve mennyiben egyéb okok, melyek csak az adott kibocsátó ország jellemzőihez köthetők.

2010-rôl 2013-ra a vizsgált országok átlagában az átutazó turisták költése folyó áron 1,03-szorosára növekedett. A 8. táblázatban az összes változás oszlop esetében azon országoknál láthatunk 100-at, ahol ennél az értéknél nagyobb, míg azoknál -100-at, ahol ennél alacsonyabb volt a növekmény. A változás két részre osztható. A területi összetevőn azt értjük, hogy az összváltozáson belül mekkora a szerepe az egyes országokhoz kötődő egyedi folyamatoknak. Költésszerkezeti összetevő azt fejezi ki, hogy a kiadások változásán belül mekkora a szerepe a költségtípusok összköltségen belüli alakulásának a vizsgált országok összességében.

Megállapítható, hogy az egyes országokhoz köthető összetevő a legtöbb esetben nagyobb jelentőséggel bír, mint a költésszerkezet, hiszen abszolút értékben a hozzá tartozó százalékos értékek magasabbak.

A költés 2010 és 2013 közötti változásának összetevői

8. táblázat

Changes in the components of spending between 2010 and 2013

\begin{tabular}{l|r|r|r}
\hline \multicolumn{1}{c|}{ Ország } & Összes változás & Területi & Költésszerkezeti \\
\hline Ausztria & $-100,0$ & $-11696,3$ & 11596,3 \\
Csehország & 100,0 & 100,5 & $--0,5$ \\
Horvátország & $-100,0$ & $-101,5$ & 1,5 \\
Lengyelország & 100,0 & 101,5 & $-1,5$ \\
Németország & $-100,0$ & $-152,9$ & 52,9 \\
Olaszország & 100,0 & 24,9 & 75,1 \\
Románia & $-100,0$ & $-78,3$ & $-21,7$ \\
Szerbiaa) & 100,0 & 91,5 & 8,5 \\
Szlovákia & $-100,0$ & 1119,9 & $-1219,9$ \\
Szlovénia & $-100,0$ & $-97,8$ & $-2,2$ \\
Ukrajna & 100,0 & 106,4 & $-6,4$
\end{tabular}

a) Montenegróval és Koszovóval együtt.

A 9. táblázat azt mutatja, hogy a kiadások 2010 és 2013 közötti változása elsősorban Szerbia (Montenegróval és Koszovóval együtt) átutazóit érintette, akiket Ukrajna és Lengyelország követ. Az átlaghoz képest kisebb változás Románia, Németország 
és Horvátország állampolgáraira jellemző. A területiség pozitív és negatív szerepe éppen azokban az országokban emelhető ki, melyeket az összváltozásnál említettünk. A költésszerkezet változása Németország, Szerbia (Montenegróval és Koszovóval együtt), valamint Olaszország állampolgárai tekintetében haladta meg legnagyobb mértékben az átlagot, míg Románia, Szlovákia és Ukrajna esetében a legnagyobb mértékben maradt el attól.

9. táblázat

A költések 2010 és 2013 közötti változásának összetevői

Changes in the components of spending between 2010 and 2013

\begin{tabular}{l|r|r|r|r|r|r}
\hline \multicolumn{1}{c|}{ Ország } & Összes+ & Összes- & Területi+ & Területi- & $\begin{array}{c}\text { Költés- } \\
\text { szerkezeti+ }+\end{array}$ & $\begin{array}{c}\text { Költés- } \\
\text { szerkezeti- }\end{array}$ \\
\hline Ausztria & 0,0 & 0,0 & 0,0 & 1,2 & 6,7 & 0,0 \\
Csehország & 12,0 & 0,0 & 12,4 & 0,0 & 0,0 & 0,3 \\
Horvátország & 0,0 & 17,0 & 0,0 & 17,7 & 1,5 & 0,0 \\
Lengyelország & 16,7 & 0,0 & 17,5 & 0,0 & 0,0 & 1,5 \\
Németország & 0,0 & 18,1 & 0,0 & 28,5 & 54,6 & 0,0 \\
Olaszország & 3,7 & 0,0 & 0,9 & 0,0 & 15,6 & 0,0 \\
Románia & 0,0 & 62,2 & 0,0 & 50,0 & 0,0 & 76,9 \\
Szerbiaa) & 44,7 & 0,0 & 42,0 & 0,0 & 21,6 & 0,0 \\
Szlovákia & 0,0 & 0,2 & 2,1 & 0,0 & 0,0 & 12,6 \\
Szlovénia & 0,0 & 2,5 & 0,0 & 2,6 & 0,0 & 0,3 \\
Ukrajna & 23,0 & 0,0 & 25,1 & 0,0 & 0,0 & 8,4 \\
\hline \multicolumn{1}{c}{ Összesen } & 100,0 & 100,0 & 100,0 & 100,0 & 100,0 & 100,0
\end{tabular}

a) Montenegróval és Koszovóval együtt.

10. táblázat

\section{Az országok csoportosítása a költések 2010 és 2013 közötti változásának összetevői szerint}

Grouping of countries by changes

in the components of spending between 2010-2013

\begin{tabular}{l|l|l|l}
\hline $\begin{array}{c}\text { Területi+ és } \\
\text { Költésszerkezeti+ }\end{array}$ & $\begin{array}{c}\text { Területi+ és } \\
\text { Költésszerkezeti- }\end{array}$ & $\begin{array}{c}\text { Területi- és } \\
\text { Költésszerkezeti+ }\end{array}$ & $\begin{array}{c}\text { Területi- és } \\
\text { Költésszerkezeti- }\end{array}$ \\
\hline Olaszország & Csehország & Ausztria & Románia \\
Szerbiaa) & Lengyelország & Horvátország & Szlovénia \\
& Szlovákia & Németország & \\
& Ukrajna & &
\end{tabular}

a) Montenegróval és Koszovóval együtt.

Területi Statisztika, 2016, 56(4): 455-476; DOI: 10.15196/TS560406 
A költések változásának elemzése után megvizsgáltuk, hogy 2009-ről 2013-ra milyen szerepe volt a látogatók számának, illetve költésének változásában az országos folyamatoknak, a szezonalitásnak, a folyamatok negyedévenkénti alakulásának, illetve az egyes országokhoz köthető helyi okoknak. Megállapítható, hogy mind az átutazó látogatók száma, mind kiadásai tekintetében a legfontosabb tényező a vizsgált időszakban a Magyarország átutazó forgalmát átlagosan jellemző általános tendencia. Az átutazás legfontosabb folyamatai tehát nem az átutazók negyedéves szerkezetének alakulásától, illetve a kibocsátó országok valamilyen speciális tényezőjétől függnek, hanem alapvetően az általános európai trendektől, illetve a Magyarország által az átutazók számára biztosított feltételektól.

A negyedéves struktúra, vagyis a negyedéves eloszlások hatása a látogatók számának változására marginális, mig a kiadásokra már nagyobb jelentöségú. Míg a látogatók számában bizonyos országoknál ez a tényező még pozitív előjelű is, a költésekben már mindenütt negatív előjelű. Ez azt jelzi, hogy a 2009-rôl 2013-ra több negyedévben az éves átlagnál alacsonyabb volt a növekedés. A kibocsátó országhoz köthető ok mind a látogatók száma, mind kiadása tekintetében pozitívan és negatívan is befolyásolta az alapvetóen az országos folyamatok által meghatározott tendenciákat. Az egyedi tényezők szerepe a látogatók száma tekintetében némileg nagyobb, mint a költések esetében.

\section{Az átutazási céllal Magyarországra látogatók számában 2009 és 2013 között bekövetkezett változás tényezői}

Factors of the change in the number of people visiting Hungary for transit purposes between 2009 and 2013

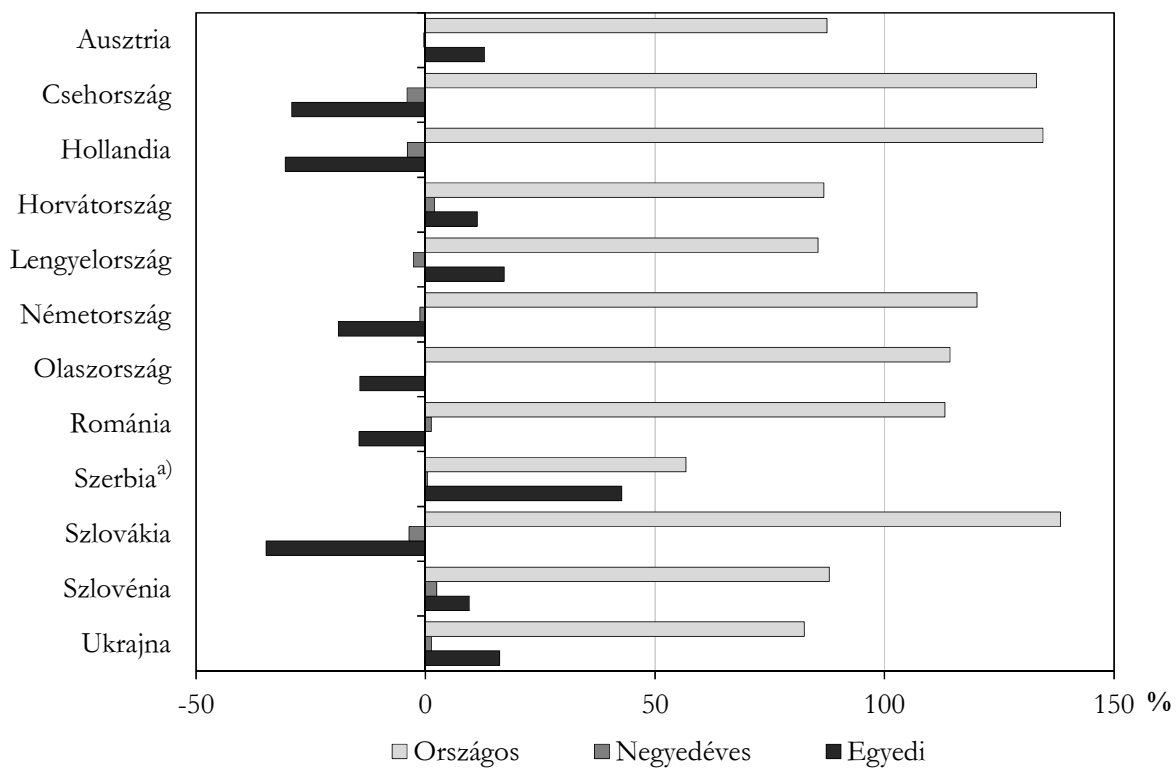

a) Montenegróval és Koszovóval együtt. 


\section{Az átutazási céllal Magyarországra látogatók költésében 2009 és 2013 között bekövetkezett változás tényezői}

Factors of the change in the spending of people visiting Hungary for transit purposes between 2009 and 2013

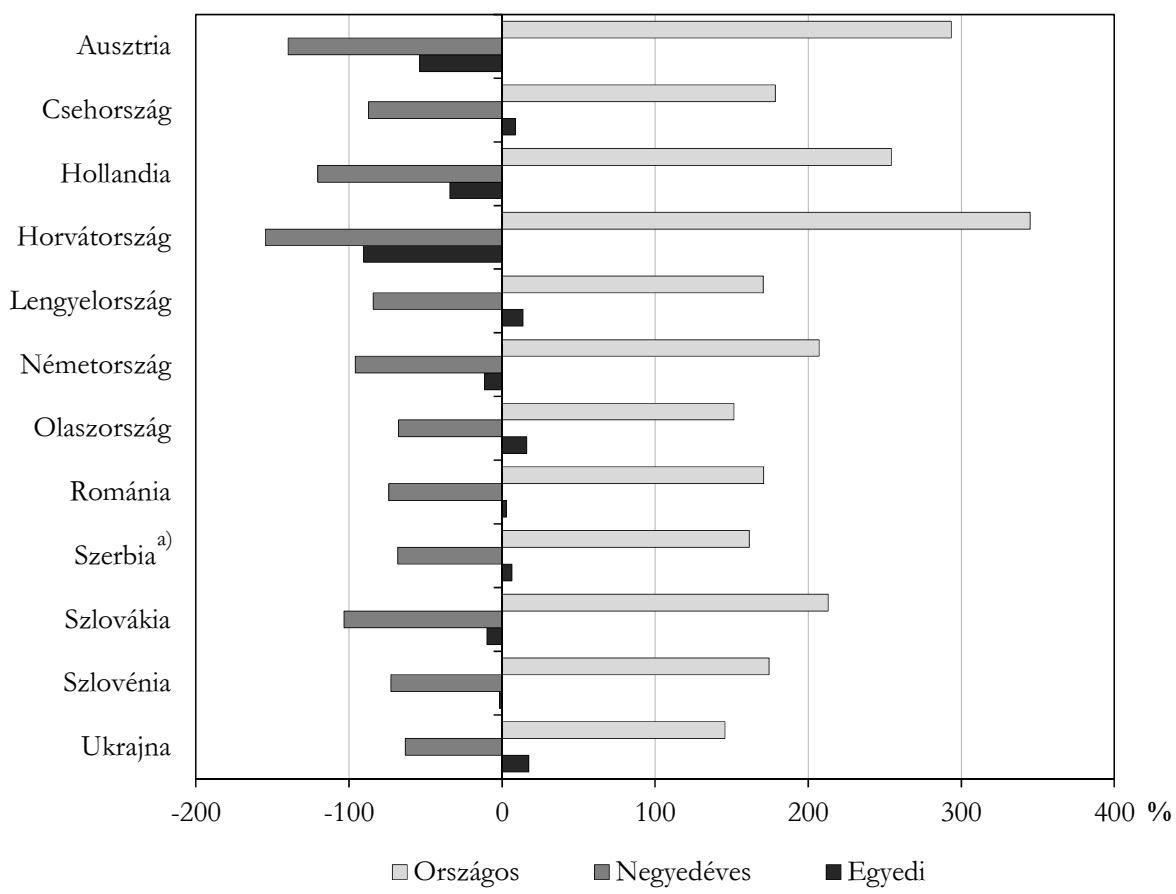

a) Montenegróval és Koszovóval együtt.

Megvizsgáltuk azt is, hogy az egy főre jutó költés mennyiben függ attól, hogy az adott átutazó mely időszakban (negyedévben) utazik át hazánkon, illetve mennyiben attól, hogy mely ország állampolgára.

A 11. táblázatban a bevételtöbblet/hiány oszlopnál azon országok mellett szerepel 100, ahol a vizsgált országok átlagánál magasabb volt a fajlagos költés 2013-ban. Értelemszerủen ott szerepel -100, ahol az alacsonyabb volt az átlagnál. Megállapítható, hogy az egy látogatóra jutó költést leginkább az határozza meg, hogy a látogató honnan, mely kibocsátó országból érkezik. Erre utal, hogy abszolút értékben a területiség hatása a legtöbb ország esetében fontosabb, mind a negyedéves struktúráé.

Területi Statisztika, 2016, 56(4): 455-476; DOI: 10.15196/TS560406 
A bevételtöbblet/-hiány és összetevői az átutazók körében, 2013

Revenue surplus/deficit and its components among transit travellers, 2013

\begin{tabular}{l|c|c|c}
\hline \multicolumn{1}{c|}{ Ország } & $\begin{array}{c}\text { Bevétel- } \\
\text { többlet/-hiány }\end{array}$ & Területi & Negyedéves \\
\hline Ausztria & $-100,0$ & $-101,1$ & 1,1 \\
Bulgária & 100,0 & 90,7 & 9,3 \\
Csehország & $-100,0$ & $-18,5$ & $-81,5$ \\
Hollandia & 100,0 & 125,0 & $-25,0$ \\
Horvátország & $-100,0$ & $-103,8$ & 3,8 \\
Lengyelország & $-100,0$ & $-60,1$ & $-39,9$ \\
Németország & 100,0 & 103,9 & $-3,9$ \\
Olaszország & 100,0 & 99,4 & 0,6 \\
Románia & 100,0 & $-263,1$ & 363,1 \\
Szerbiaa) & $-100,0$ & $-104,5$ & 4,5 \\
Szlovákia & $-100,0$ & $-90,0$ & $-10,0$ \\
Szlovénia & $-100,0$ & $-100,3$ & 0,3 \\
Ukrajna & 100,0 & 98,5 & 1,5
\end{tabular}

a) Montenegróval és Koszovóval együtt.

A 12. táblázat szerint az egy látogatóra jutó költés Ukrajna, Németország és Bulgária állampolgárai esetében haladja meg legnagyobb mértékkel az átlagost. Ezzel ellentétben Szerbia (Montenegróval és Koszovóval együtt), valamint Szlovákia és Horvátország jellemezhető a legalacsonyabb fajlagos költéssel. Az adott országhoz köthető helyi okok befolyásolják elsősorban Ukrajna, Németország és Bulgária átutazó állampolgárai körében pozitívan az egy látogatóra jutó költést, míg Szerbia (Montenegróval és Koszovóval együtt), valamint Szlovákia és Horvátország esetében negatívan. A negyedéves összetétel, vagyis a magas átlagos egy főre jutó költéssel rendelkező negyedév(ek) felülreprezentáltsága Románia, Bulgária, valamint Szerbia (Montenegróval és Koszovóval együtt) állampolgáraira jellemző. Ezzel ellentétes tendencia figyelhető meg a Lengyelországból, a Szlovákiából és a Csehországból induló és Magyarországon átutazók esetében. 


\section{A bevételtöbblet/-hiány és összetevőinek szerepe} az átutazók körében, 2013

Revenue surplus/deficit and the role of its components among transit travellers, 2013

\begin{tabular}{l|c|c|c|c|c|c}
\hline \multirow{2}{*}{\multicolumn{1}{c|}{ Ország }} & \multicolumn{2}{|c|}{$\begin{array}{c}\text { A bevételtöbblet/ } \\
\text {-hiány szerepe }\end{array}$} & \multicolumn{2}{c|}{$\begin{array}{c}\text { A területiség } \\
\text { szerepe }\end{array}$} & \multicolumn{2}{c}{$\begin{array}{c}\text { A negyedéves } \\
\text { Összetétel szerepe }\end{array}$} \\
\cline { 2 - 7 } & pozitív & negatív & pozitív & negatív & pozitív & negatív \\
\hline Ausztria & 0,0 & 12,8 & 0,0 & 13,3 & 1,5 & 0,0 \\
Bulgária & 21,3 & 0,0 & 19,9 & 0,0 & 20,1 & 0,0 \\
Csehország & 0,0 & 2,4 & 0,0 & 0,5 & 0,0 & 20,0 \\
Hollandia & 1,5 & 0,0 & 1,9 & 0,0 & 0,0 & 3,7 \\
Horvátország & 0,0 & 14,5 & 0,0 & 15,5 & 5,5 & 0,0 \\
Lengyelország & 0,0 & 10,5 & 0,0 & 6,5 & 0,0 & 42,6 \\
Németország & 23,4 & 0,0 & 25,1 & 0,0 & 0,0 & 9,3 \\
Olaszország & 11,0 & 0,0 & 11,2 & 0,0 & 0,6 & 0,0 \\
Románia & 1,4 & 0,0 & 0,0 & 3,9 & 52,9 & 0,0 \\
Szerbiaa & 0,0 & 27,2 & 0,0 & 29,3 & 12,6 & 0,0 \\
Szlovákia & 0,0 & 24,0 & 0,0 & 22,2 & 0,0 & 24,4 \\
Szlovénia & 0,0 & 8,6 & 0,0 & 8,9 & 0,2 & 0,0 \\
Ukrajna & 41,4 & 0,0 & 42,0 & 0,0 & 6,5 & 0,0 \\
\hline
\end{tabular}

a) Montenegróval és Koszovóval együtt.

A Magyarországra átutazási céllal látogatók utazásának szezonalitását is megvizsgáltuk. A szezonalitást a legmagasabb és a legalacsonyabb értékkel rendelkező negyedév hányadosának számításával számszerűsítettük. Megállapíthatjuk, hogy a vizsgált országok körében 2009 és 2013 között a szezonalitás mértéke csökkent. Az átutazóforgalmon belül a lengyel, a szlovák és a holland állampolgárok mutatják a legnagyobb, míg a bolgár, a román és a horvát állampolgárok a legkisebb szezonalitást.

Területi Statisztika, 2016, 56(4): 455-476; DOI: 10.15196/TS560406 
13. táblázat

A legmagasabb és a legalacsonyabb látogatószámú negyedévek hányadosa

Quotient of the quarters with the highest and lowest number of visitors

\begin{tabular}{l|r|r|r|r|r}
\hline \multicolumn{1}{c|}{ Ország } & 2009 & 2010 & 2011 & 2012 & 2013 \\
\hline Ausztria & 4,6 & 3,1 & 4,0 & 2,3 & 2,3 \\
Bulgária & - & - & 1,7 & 1,7 & 1,4 \\
Csehország & 11,4 & 12,5 & 14,1 & 13,4 & 7,2 \\
Hollandia & 9,7 & 12,9 & 11,1 & 16,0 & 8,5 \\
Horvátország & 1,5 & 1,5 & 1,9 & 1,2 & 1,8 \\
Lengyelország & 11,3 & 8,7 & 11,1 & 8,0 & 9,7 \\
Németország & 3,6 & 4,7 & 3,8 & 3,7 & 3,4 \\
Olaszország & 2,1 & 2,3 & 2,3 & 2,7 & 2,4 \\
Románia & 1,7 & 1,7 & 1,7 & 1,7 & 1,8 \\
Szerbiaa) & 1,3 & 1,8 & 2,1 & 1,9 & 2,4 \\
Szlovákia & 10,5 & 11,1 & 21,5 & 9,0 & 7,4 \\
Szlovénia & 1,2 & 1,7 & 133,4 & 1,7 & 2,9 \\
Ukrajna & 1,7 & 1,6 & 2,6 & 1,7 & 2,0
\end{tabular}

a) Montenegróval és Koszovóval együtt.

\section{Következtetések}

Kutatásunk legfontosabb célja az volt, hogy korábbi tanulmányunk (Kincses et al. 2014) kutatási eredményein alapulva ráirányítsuk a figyelmet az átutazó turizmus szerepére és adatokkal igazoljuk annak jelentőségét. Vizsgálataink egyértelműen bizonyítják azt, hogy a téma viszonylagos szakirodalmi elhanyagoltsága ellenére mégis tudományos igényú elemzést igényel. Ezt bizonyítja, hogy a Magyarországra érkező külföldiek költési összetételében az átutazók részesedése jelentős, és költéseik folyamatosan nőnek. 2009 és 2013 között az átutazók motivációi némileg átalakultak, a klaszszikus célokat újak váltották fel. Ezekre a turisztikai szakmának és a gazdasági döntéshozatalnak is érdemes felkészülnie.

Vizsgálataink is igazolták, hogy az átutazásnak legfontosabb költéstípusai az üzemanyag-vásárlás és a vendéglátóhelyi étkezés. A Magyarországon átutazó látogatók közül Románia, Szerbia (Montenegróval és Koszovóval együtt), valamint Bulgária állampolgárainak részesedése a legnagyobb. A vizsgált időszakban az átutazó külföldiek kiadása és száma is enyhén emelkedett. Viszont az egy látogatóra jutó kiadások csökkentek. Kimutattuk, hogy ennek oka az országok közötti átrendeződésben keresendő.

Rámutattunk arra, hogy az átutazásra fordított költések változása tekintetében az egyes országokhoz való tartozás sokkal fontosabb annál, mint az, hogy milyen szerkezetben költik el pénzüket hazánkban az átutazók. Emellett azt is megállapítottuk, hogy az átutazás legfontosabb folyamatai nem az átutazók negyedéves szerkezetének alakulásától, illetve a kibocsátó országok speciális jellemzőitől függnek, hanem alap- 
vetően az általános európai trendektől, illetve a Magyarország által az átutazók számára biztosított feltételektől. Ezeket az európai trendeket folyamatosan követve - véleményünk szerint - szükséges, hogy a hazai turisztikai élet minden szereplöje megfelelő döntéseket hozzon annak érdekében, hogy az átutazó turizmus gazdasági előnyeiből minél nagyobb mértékben részesedhessen, illetve annak kedvezőtlen hatásait minél nagyobb mértékben elkerülhesse.

\section{Köszönetnyilvánítás}

A tanulmány elkészítését lehetôvé tevő kutatást az OTKA K 100953 projektje támogatta.

\section{IRODALOM}

ANDrikopolous, A. B. J.-CARVALHO, E. (1990). Shift-share analysis and the potential for predicting regional growth patterns: some evidence for the region of Quebec, Canada Growth and Change 21 (1): 1-10.

BAKIC, O. (1988): Yugoslavian tourism - strategic planning of destination product Tourism Management 9 (2): 145-151.

BöHLER, S.-GrischKat, S.-HAustein, S.-HuneCKe, M. (2006): Encouraging environmentally sustainable holiday travel Transportation Research Part A: Policy and Practice 40 (8): 652-670.

COOPER, CH-HALL, M. (2016): Contemporary tourism - an international approach Goodfellow Publishers Limited, Oxford.

De Cantis, S.-Parroco, A.-Ferrante, M.-Vaccina, F. (2015): Unobserved tourism Annals of Tourism Research 50: 1-18.

Filimonau, V.-Dickinson, J.-RobBins, D. (2014): The carbon impact of short-haul tourism: a case study of UK travel to Southern France using life cycle analysis Journal of Cleaner Production 64 (1): 628-638.

Fuchs, M.-RijKen, L.-Peters, M.-Weiermair, K. (2000): Modelling Asian incoming tourism: a shift-share approach Asia Pacific Journal of Tourism Research 5 (2): 1-10.

GOPALAN, R.-NARAYAN, B. (2010): Improving customer experience in tourism: A framework for stakeholder collaboration Socio-Economic Planning Sciences 44 (2): 100-112.

GRAHAM, A. (2009): How important are commercial revenues to today's airports? Journal of Air Transport Management 15 (3): 106-111.

GrEEN, F. (1978): Recreation vehicles - a perspective Annals of Tourism Research 5 (4): 429-439.

HALL, D. (1998): Tourism development and sustainability issues in Central and South-eastern Europe Tourism Management 19 (5): 423-431.

Houston, D. B. (1967): The shift and share analysis of regional growth: a critique Southern Economic Journal 33 (4): 577-581.

JOHNSON, M. (1995): Czech and Slovak tourism - patterns, problems and prospects Tourism Management 16 (1): 21-28.

KinCSES, Á.-MichALKÓ, G.-TÓTH, G. (2014): A Magyarország átutazó forgalmában érintett települések lehatárolása Terïleti Statisztike 54 (3): 237-252.

Laviolette, P. (2016): Why did the Anthropologist Cross the Road? Hitch-Hiking as a Stochastic Modality of Travel Ethnos 81 (3): 379-401

Területi Statisztika, 2016, 56(4): 455-476; DOI: 10.15196/TS560406 
Lohmann, G.-Albers, S.-Koch, B.-Pavlovich, K. (2009): From hub to tourist destination - An explorative study of Singapore and Dubai's aviation-based transformation Journal of Air Transport Management 15 (5): 205-211.

Malone, J.-Brigantic, R.-Muller, G.-Gadgil, A.-Delp, W.-McMahon, B.-Lee, R. -KulESZ, J.-MineliC, M. (2009): U.S. airport entry screening in response to pandemic influenza: Modeling and analysis Travel Medicine and Infectious Disease 7 (4): 181-191.

MichalKó, G. (2012): Turizmológia Akadémiai Kiadó, Budapest.

MichalkÓ, G.-RÁTZ, T. (2013): Rejtett dimenziók a Kárpát-medence turizmusában In: FRISNYÁK, S.-GÁL, A. (szerk.): Kárpát-medence: természet, társadalom, gazdaság pp. 463-476., Bocskai István Gimnázium - Nyíregyházi Főiskola Turizmus és Földrajztudományi Intézet, Szerencs - Nyíregyháza.

Michaud, A. (1991): A social anthropology of tourism in Ladakh, India Annals of Tourism Research 18 (4): 605-621.

Parroco, A.-Vaccina, F.-De Cantis, S.- Ferrante, M. (2012): Multi-destination trips and tourism statistics: empirical evidences in Sicily. Economics: The Open-Access Open-Assessment E-Journal 6 (2012-44): 1-27.

Prager, F.-Rose, A.-Wei, D.-Roberts, B.-Baschnagel, CH. (2015): Economy-wide impacts of reduced wait times at U.S. international airports Research in Transportation Business \& Management 16: 112-120.

RÁTZ, T. (2004): European Tourism Kodolányi János Főiskola, Székesfehérvár.

Schiefelbusch, M.-JAIN, A.-Schafer, T.-MÜller, D. (2007): Transport and tourism: roadmap to integrated planning developing and assessing integrated travel chains Journal of Transport Geography 15 (2): 94-103.

Selting, A. C.-LOVERIDGE, S. (1992): A summary of the literature on shift-share analysis Department of Agricultural and Applied Economics, University of Minnesota College of Agriculture St. Paul, Minnesota USA.

SIRAKAYA, E.-CHOI, H. S.-VAR, T. (2002). Shift-share analysis in tourism: examination of tourism development change in a region Tourism Economics 8 (3): 303-324

Stevens, B. H.- MoOre, C. L. (1980): A critical review of the literature on shift-share as a forecasting technique Journal of Regional Science 20 (4): 419-437.

SuH, Y.-MCAvoy, L. (2005): Preferences and trip expenditures - a conjoint analysis of visitors to Seoul, Korea Tourism Management 26 (3): 325-333.

TOH, R. S.-KHAN, H.-LIM, L. L. (2004). Two-stage shift-share analyses of tourism arrivals and arrivals by purpose of visit: the Singapore experience Journal of Travel Research 43 (1): 57-66.

UNWTO 2015: Tourism Highlights 2015 UNWTO, Madrid.

Volo, S.-Giambalvo, O. (2008): Tourism Statistics: Methodological Imperatives and Difficulties: The Case of Residential Tourism in Island Communities Current Issues in Tourism 11 (4): 369-380.

WynEN, J. (2013): Explaining travel distance during same-day visits Tourism Management 36: $133-140$.

YAsin, M.-Alavi, J.-Sobral, F.-LisbOA, J. (2004). A shift-share analysis approach to understanding the dynamic of the Portuguese tourism market Journal of Travel and Tourism Marketing 17 (4): 11-22.

Yousuf, M.-BACKER, E. (2015): A content analysis of Visiting Friends and Relatives (VFR) travel research Journal of Hospitality and Tourism Management 25: 1-10.

Területi Statisztika, 2016, 56(4): 455-476; DOI: 10.15196/TS560406 